\title{
The Effect of Explicit Affective Strategy Training on Iranian EFL learners' Oral Language Proficiency and Anxiety Reduction
}

\author{
Fatemeh Mostafavi \\ Department of English, College of Persian Literature and Foreign Languages, \\ Ardabil Branch, Islamic Azad University, Ardabil, Iran \\ E-mail: f_msv@yahoo.com \\ Fereidoon Vahdany \\ Payame-Noor University, Tehran, Iran \\ E-mail: Frvahdany@gmail.com
}

Doi:10.7575/aiac.alls.v.7n.4p.197

URL: http://dx.doi.org/10.7575/aiac.alls.v.7n.4p.197
Received: $15 / 04 / 2016$

Accepted: 26/06/2016

\begin{abstract}
The current study aimed at investigating the possible effects of explicit teaching of affective strategies on Iranian EFL learners' oral language proficiency and the extent of their anxiety in EFL classroom. First, PET test was administered to a total number of 120 female third grade high school EFL students. Then, 60 participants whose score fell within the range of $\pm 1 \mathrm{SD}$ from the mean score were selected for the main study. Next, they were randomly assigned into two groups (one control and one experimental). The design of the study was Experimental comparison-group plan. Foreign Language Classroom Anxiety Scale adopted from Horwitz (1986) was used to examine the EFL learners' anxiety level in English class. Moreover, two equivalent oral tests adopted from Heaton (1975) were administered to the participants of the two groups both at the beginning and at the end of the study served as pre and post-tests. The treatment for the experimental group included Oxford's (1990) taxonomy of affective strategies, which included explicit affective strategy instruction (in relaxation, music, visualization, humor, positive self-talk, risk-taking, and monitoring emotions). The control group did not receive any special instruction in terms of affective strategies. To investigate the possible effects of explicit affective strategy use instruction on the participants' oral language proficiency and their anxiety level, the pre and posttests of oral tests and the participants' self-reports of anxiety control in both groups were analyzed and compared. The results of independent samples T- test indicated that while the two groups were homogeneous in terms of oral proficiency and level of anxiety control before introducing the treatment, the experimental group performed better than the control group in the oral post-test. Moreover, the level of anxiety control for the experimental group was significantly different and higher than that of the control group. The results confirm the positive effects of affective strategy instruction on oral language proficiency. The findings of this study provide a greater understanding of affective strategy use among Iranian EFL learners. This study might also have some implications for material developers to consider strategy use in materials development.
\end{abstract}

Keywords: affective strategies, explicit strategy training, language anxiety

\section{Introduction}

In the last three decades, the field of second/foreign language teaching and learning has focused mainly on learners' individual factors. O' Malley and Chamot (1990) draw attention to the differences between more productive learners and less effective learners and relate it to the number and range of strategies they use when learners learn a language. Recently, learning strategies have been worldwide issues in English language instruction. A survey of the previous studies on language learning and teaching reflects that researches have introduced different factors that may be related to the neurological, psychological, cognitive, and affective domains such as having an ability for language learning, learning styles and strategies, social contexts, and affective factors including empathy, self-esteem, inhibition, motivation, attitudes, and anxiety (Brown, 1989). Many researchers have found that frequent uses of learning strategies are associated with great attainment in the language (Green \& Oxford, 1995; Oxford \& Burry-Stock, 1995). Oxford (1990) defines learning strategies as “...specific actions learners employ to facilitate, accelerate their learning” (p. 8). Comprehensive perception of learning strategies was facilitated when Oxford (1990) developed a questionnaire to evaluate language-learning strategies called Strategy Inventory for Language Learning (SILL). She stressed the significance of learning strategies for language learning as they led to active, self-directed involvement of the learners. In addition, many researches have reported that successful language learners are more likely to engage in active language learning and use more learning strategies than less successful learners (Bialystok, 1983; Chamot \& Küpper, 1989; Oxford \& Nyikos, 1989; Peacock \& Ho, 2003; Phillips, 1992; Politzer, 1983). It is also believed that learners' communicative proficiency can be enhanced by improving the ability to use specific communication strategies that 
enable them to compensate for the possible defects they may encounter when learning a target language deficiency (e.g. Bialystok, 1983; Dorney, 1995). Later, some researchers focused on examining the possible effects of strategies in developing a specific language skill, such as speaking, writing, reading, and listening. Learning a second language involves the manipulation of these skills that lead to effective communication. In this study, speaking skill was selected and Oxford's SILL was used as the key instrument for collecting the relevant data.

Another important issue, which is directly related to learners' language learning, is affective strategies. Language learning anxiety is a psychological construct that has important role in the domain of EFL learning (Zheng, 2008). Horwitz (2001) gives a definition of language learning anxiety and states that anxiety is a concept that has many facets. It includes self-perceptions, beliefs, feelings, and behaviors related to learning that results from the uniqueness of the language learning process. This complex concept has four components (Horwitz and Cope, 1986; Zheng, 2008) including communication anxiety, test anxiety, negative evaluation anxiety, and anxiety in the English classroom. Communication anxiety is the learners' concern over communicating with other people, which might bring them some problems with respect to speaking in public, comprehending what others say, and making themselves understood, as well as being competent listeners during the language learning process. Test anxiety is the learners' apprehension of exams, quizzes, and other evaluative activities that are used to assess their competence and performance. Negative evaluation anxiety refers to the learners' concern over how others judge them that may also include avoidance of assessment and feeling that others might judge them negatively. Anxiety in the English classroom which is the learners' concern in the classroom situation where some influential factors such as learning tasks and activities, teachers' engagement may cause language learning anxiety (Horwitz, et al. 1986; Brown, 2007;Zheng, 2008). The combination of these parts led to the anxiety in language learners (Brown, 2007; Zheng, 2008).

\subsection{Statement of the problem}

Many EFL learners seem to be unaware of the influential roles of affective factors and learning strategies in their success in language learning (Rubin and Thompson, 1996). Many of them have very limited learning strategies including translation, memorization, note taking, etc. many have inaccurate beliefs about language learning classrooms that may hinder their language learning process (Horwitz, 1986). Learning English has always been a great challenge for Iranian EFL learners. One possible reason might be that they have limited opportunities to practice English in their daily lives. Moreover, lack of direct and explicit strategy use instruction is seen in almost all the EFL classes. As review of literature shows, researchers have seldom examined the effect of variables such as affective strategy training on English oral language proficiency level and anxiety reduction in Iranian EFL situations. It has not been examined how these factors are correlated. There is not much known about the extent to which explicit strategy instruction plays a role in improving oral performance and how these affective strategies lower the Iranian EFL learners' anxiety. On the other hand, many language learners express their concern over learning a foreign language. This anxiety and negative feeling can make many serious problems in the language acquisition process and learners' achievement (MacIntyreand Gardner, 1991). In fact, this study aims to make a bridge between strategy use instructions, development of speaking ability, and lowering down the anxiety level of the earners. It is hoped that the findings help teachers to make appropriate use of strategies into their language classes and students be encouraged to make frequent use of them to have efficient language learning process.

\subsection{Significance of the study}

The main postulation underlying this study is that English language learning strategies bring success to language learners and play an important role in affecting learners' English language learning process. Increasing attention toward language learning has made researchers carefully examine various factors that could enhance learning effectiveness. Studies show that several factors are involved in the second/foreign language learning process. One of the most important elements for foreign language research is to investigate the possible association between different factors that affect language learning. This study intended to establish a direct relationship between explicit strategies use instruction and EFL learners' speaking skill as well as their anxiety level. In sum, this study intends to examine language learners' learning strategies with the belief that that consciousness of learning strategies more specifically affective strategies makes EFL learners, educators and curriculum designers more successful in their teaching and learning process. This study is significant as the affective strategies instruction develops language learners' capability in EFL learning and helps them to become independent and aware of the ways they can learn most effectively. Being aware of the important role of affective strategy instruction may enable teachers and researchers to design appropriate materials and activities to help them improve their language learning so as to enhance their speaking ability and lower the anxiety level of the language learners.

\subsection{Research Questions and Hypotheses}

The focus of the current study is on affective strategies and their effects on Iranian EFL learners' oral language proficiency and anxiety reduction. There are two main questions in this study:

RQ1. Does explicit affective strategy training significantly affect Iranian pre-intermediate EFL learners' oral proficiency?

RO2. Does explicit affective strategy training have any significant effect on Iranian pre-intermediate EFL learners' anxiety reduction?

Taking the abovementioned research questions into consideration, the following null hypothesis were formulated: 
H01. Explicit affective strategy training does not have any significant effect on Iranian pre-intermediate EFL learners' oral proficiency.

HO2. Explicit affective strategy training does not have any significant effect on EFL learners' anxiety reduction.

\section{Review of literature}

Learner-centered approaches to second language teaching have been an interesting area for foreign language learning research. The main goal is to help learners to be autonomous and independent language learners (Tamada, 1996). Furthermore, in foreign language learning research the products of language learning have given their place to the processes of learning a foreign language (Oxford, 1990). Therefore, the emphasis is now on language-learning strategies (LLSs) as essential part of different theoretical models of language expertise (Bachman and Palmer, 1996) and helping learners to be autonomous in the process of language learning (Benson and Voller, 1997).

By definition, language-learning strategies refer to the ways in which learners try to figure out the meanings and uses of words, grammatical rules, and other aspects of the language (Cohen, 1990). Today, great attention is paid to the language learning strategies in the domain of foreign language teaching and learning (Brown 1991, Cohen 1990, McDonough 1995, Mendelsohn 1994, Rubin \& Thompson 1996, Oxford 1990). Language instructors in many different language-learning situations search for the ways to help students become more prosperous learners and communicators in foreign languages. Applying foreign language learning and use strategies is regarded as effective means for fostering higher attainment (Brown, 1991). If A strategy assists the students to learn or use the foreign language it is considered to be "effective" (Oxford, 1990). In a comprehensive definition of foreign language learning and use strategies, they refer to the steps or activities that learners choose to enhance their foreign language learning (McDonough, 1995).

The main objective of using language-learning strategies is to help learners to increase the quality of their knowledge and comprehension of a target language. Language learners employ these conscious thoughts and behaviors to have promotion in their language learning tasks and to personalize the language learning process. Language learning strategies have been classified into four separate categories: cognitive, metacognitive, social, and affective (Chamot 1987, Oxford 1990). Metacognitive strategies refer to management techniques that learners use to check their learning process though programming, supervision, evaluating, and modifying their learning approaches (Rubin, 1990). Socioaffective strategies include asking for clarification, repeating, imitating, and circumlocution, cooperating, and engaging in private speech (Hall, 2001). This systematic arranging of strategies was first developed for ESL students (O'Malley et al., 1985). Afterwards, the validation of this classification was confirmed with foreign language learners, including students of Russian, Spanish, and Japanese in the United States (Barnhardt, 1992; Chamot and Kupper, 1989; Omori, 1992), English as a foreign language students in Brazil (Absy, 1992; Lott-Lage, 1993), and students of French in Canada (Vandergrift, 1992).

Oxford (1990) proposed another classification for learning strategies. She divided them into two classes including direct strategies and indirect strategies, and each class contained three subcategories. Direct strategies improve target language leaning directly. In contrast, indirect strategies assist learners to support and control language learning without directly involving the target language. Direct strategies are separated into memory, cognitive, and compensation strategies; indirect strategies are divided into metacognitive, affective, and social strategies.

The focus of the present study is on Affective strategies. These strategies adjust learner motivation, feelings, and attitudes. Through using affective strategies, language learners can lower anxiety by implementing some mental techniques and solve problems through teacher-student or peer interactions (O'Malley \& Chamot, 1990). The significance of affective factor led some approaches and studies (ex: humanism, the silent way, community language learning) to pay attention to the concept of educating the "whole person." Methods such as Community Language Learning (Curran, 1972) and Suggestopedia (Lozanov, 1979) used this affective approach. Stevick (1980) argued that " ... [language learning] success depends less on materials, techniques and linguistic analyses, and more on what goes on inside and between the people in the classroom" (p. 4). Krashen (1982) stated that when learners are anxious or bored, an internal barrier hinders second language acquisition. Schumann $(1997,2001)$, proposed that factors such as psychology and neurobiology of stimulus appraisal affect the degree to which second language learning is achieved.

Finch (2000) expressed the need for teachers to consider students' affective natures and needs, not simply to help them to have lives that are more satisfying and to be responsible members of society, but also in order to improve their education. Chou (2004) gave reasons for the use of affective strategies. He argued that these strategies could both help EFL learners manage their feelings and attitudes towards learning and learn to interact with others in a prosperous manner (Chou, 2004).

Habte-Gabr (2006) showed that affective strategies should be considered as one of the main principles of EFL learning. $\mathrm{He}$ stated that the use of affective strategies helps language learners to learn how to learn since they expect the instructor to be as a resource for language and content and provide emotional support for the learners.

Dörnyei (2001, p. 116) suggests, "Teacher skills in helping learners should be considered as central to teaching effectiveness." The implication might be that teachers should be familiar with general affective and motivational concepts in language learning; besides, they should be able to implement them in their classes.

Oxford and Nyikos (1989), show that the degree of motivation and other affective factors have the most powerful influence on how and when students use language-learning strategies. Scimonelli (2002) maintains that affective and social language learning strategies as well as communication strategies are the areas in which the teacher's intervention 
should come first, in order to develop positive pictures of mind in the students and help them overcome the stress and sense of discomfort that is sometimes caused by a poor or low oral command of English. Additionally, Bialystock (1978) recognizes that when learners communicate in the target L2, they can consciously make use of language-learning strategies in order to handle the difficulties they face.

Many research studies support the positive effects of strategy instruction on language learning performance (Carrell, Pharis, \& Liberto, 1989; Carrell, 1998; Oxford 1990a, 1990b, 1996; Oxfordet al., 1990). Cottrell (1999) claims that through practice and instruction, learners' use of strategies can be automatized. The main goal of the teaching approach that is based on language learning strategy instruction is to improve learner awareness of learning strategies and provide learners with systematic practice, reinforcement and self-monitoring of their strategy use while attending to language learning activities (Cohen, 1998). The main assumption of strategy instruction is, if learners explore 'how', 'when', and 'why' to use language learning strategies, and assess and regulate their own learning (Cohen, 1998, p.69), then they can take a more active role in language learning process. The advantage of becoming active participants in the learning process is that they can enjoy more efficient and beneficial language learning. Reactive approach in learning (Hedge, 1993, p.92) will lead to procedural knowledge of learning strategies. This approach enhances motivation levels, improves self-efficacy, encourages learner independence, intensifies transfer skills, and develops language proficiency.

Strategy instruction helps learners to understand and learn new material or skills successfully with appropriate tools and techniques. Teaching strategies supplies long lasting guidance for the learners and provides many opportunities for practice. This assists learners to know how to integrate knowledge in a way that helps them to remember it later, even in a different situation or environment. Researchers (O'Malley, Chamot, Stewner- Manzanares, Küpper \& Russo, 1985, as cited in Chamot, 1993) have studied the results of language learning strategies that were taught to English as second language (ESL) learners in numerous different tasks, including vocabulary, listening, and speaking tasks. The outcomes of the studies reveal that language-learning strategies are mainly advantageous for the speaking task (Chamot, 1993).

Various researchers have investigated the strategies used by students. Some Researchers (Chamot \& Küpper, 1989) assert that the cognitive strategies are the most frequently used strategy. Meanwhile, learners use far fewer metacognitive strategies than cognitive strategies, and they rarely employ affective strategies. Some other researchers (ex: Goh \& Kwah, 1997) report high use of metacognitive strategies and low use of affective strategies; in other words, students regularly employ metacognitive strategies in language learning and rarely utilize affective strategies. The earlier research studies have shown a consistent perspective that language learners tend not to use affective strategies in language learning. Furthermore, the results of the studies on strategy description and categorization have suggested useful implications for language classrooms with respect to the influential roles of strategies in helping teachers accelerate the language learning of their students. The findings of many studies have suggested that learning strategy instruction may help learners to become better learners or assist them in becoming autonomous and confident learners. Besides, strategy use may help learners to become more motivated as they begin to understand the relationship between their use of strategies and success in learning languages (Chamot \& Kupper, 1989; Chamot \& O'Malley, 1994). However, the main point is that these earlier studies in the domain of foreign language learning strategies indicate that language learners are inclined to use simply a series of limited learning strategies and learners frequently overlook affective strategies. Consequently, this study intends to provide Iranian EFL students and language teachers with effective strategies. It is hoped that these affective strategies help learners and educators to successfully promote speaking competence.

\section{Method}

\subsection{The Design of the Study}

The design of the study was true experimental design in which control and experimental groups were selected randomly and were compared at both the beginning of the study and after the intervention of the specific treatment for the experimental group and giving the placebo to the control group. The following table presents the design of the study.

Table 3.1 The design of the study

\begin{tabular}{l|l}
\hline Experimental group & Control group \\
\hline Participants: 30 female grade three high school learners & Participants: 30 female grade three high school learners \\
Step 1: Oral pretest administration & Step 1: Oral pretest administration \\
Step 2: Questionnaire administration & Step 2: Questionnaire administration \\
Step 3: Treatment(affective strategy training) & Step 3: Placebo (no strategy training) \\
Step 4: Oral posttest administration & Step 4: Oral posttest administration \\
Step 5: questionnaire administration & Step 5: questionnaire administration \\
\hline
\end{tabular}


The main participants included an English teacher and $(n=60)$ female third grade students at a high school in Tehran, Iran. Their field of study included natural science, human science, and mathematics. Their ages ranged from 16 to 18. To ensure that they were homogeneous in terms of their English language proficiency at the beginning of the study, they were given a Preliminary English test (PET). Their English proficiency scores ranged from 12 to 76 on PET test. The main sample was selected from among 120 students whose score fell within the range of \pm 1 SD from the mean score on PET test.

\subsection{Instruments and Materials}

The following instruments were used in this study:

1. Preliminary English Test (PET),

2. A questionnaire that reflected the learners' self-reports on their anxiety level in English class both at the beginning and at the end of the study,

3. Materials which were prepared for the treatment phase, and

4. Oral language proficiency tests both at the beginning and at the end of the study.

\subsubsection{Preliminary English Test (PET)}

To make certain that the subjects were approximately at the same level of language proficiency, the Preliminary English Test was administered to 120 students. The Preliminary English Test is one of the Cambridge ESOL exams. It tests language ability at pre-intermediate level. The participants took the structure, vocabulary, and reading comprehension sections of the test with a maximum possible score of 100 points.

\subsubsection{Questionnaire}

Foreign Language Classroom Anxiety Scale (FLCAS) which included ( $\mathrm{n}=30$ ) items and was designed by Horwitz et al. (1986) was used to assess the participants' language learning anxiety both at the beginning and at the end of the study. The original Foreign Language Classroom Anxiety Scale (FLCAS) is a 30 items questionnaire, 5-point Likert scale survey that is widely used in research studies. The measure scrutinizes participants' communication apprehension, testanxiety, and fear of negative evaluation; and focuses on speaking in a classroom context. The FLCAS has been used worldwide for students of second and foreign languages in settings such as university, school and government (Yang, 1992).

\subsubsection{Instruments for the Treatment Phase}

Chamot (1999) states that since learning strategies are mental processes and consequently have limited discernable manifestations, teachers need to find ways to make the strategies as tangible as possible. For this purpose, Affectbased activities adopted from Oxford, 1990 were used as instruments for the treatment phase of the study (see table 3. 2).

Table 3.2 Oxford's (1990) taxonomy of affective strategies

\begin{tabular}{l|l}
\hline Strategy (Oxford, 1990) & Sample activity \\
\hline Lowering your anxiety & Speaking strategies (Weaver \& Cohen, 1997) \\
& Relaxation exercises (Moskowitz, 1978) \\
& Music \\
& Humor: Video: The Best of Mr. Bean \\
\hline Encouraging yourself & Speaking strategies (Weaver \& Cohen, 1997) \\
& Positive self-talk (adapted from Powell, 1997) \\
& Discussing and taking risks (Brown, 1989) \\
\hline Taking your emotional temperature & Speaking strategies (Weaver \& Cohen, 1997) \\
& Feelings checklist (Oxford, 1990) \\
& Language learning journal (Nunan, 1996) \\
& SLL advice column (Crookall \& Oxford, 1991) \\
\hline
\end{tabular}

\subsubsection{Instruments to test learners' performance on oral proficiency}

Young (1991) states that any kind of teaching has need for evaluation and teaching strategies, by itself, is not an exception. In this study, evaluation of oral $t$ proficiency was done through a test constructed for this purpose. Two oral tests based on narrative task and picture strips from Heaton (1975) were administered as pre and posttest to the subjects to assess their oral proficiency both at the beginning and at the end of the study.

\subsection{Data collection Procedure}

Prior to the beginning of the term, the researcher explained the intervention procedure to the teacher who taught both the experimental and control groups. The research lasted for 7 weeks. The study used Oxford's (1990) taxonomy of affective strategies, to determine the effects of explicit affective strategy instruction (in relaxation, music, visualization, 
humor, positive self-talk, risk-taking, and monitoring emotions) on Iranian EFL learners' oral proficiency. An experimental comparison-group design was used, in which one group of EFL learners received six weeks of affective strategy instruction and the second served as a comparison group and received placebo. Both groups took part in an oral posttest to compare the degree of their oral proficiency improvement and to examine the effects of strategy training.

The explicit affective strategy instruction included consciousness-raising activities and training in relaxation (e.g., Moskowitz, 1978), visualization (e.g., Arnold, 1999), positive self-talk (e.g., Oxford, 1990), humor (e.g., Mr. Bean videos), risk-taking (Brown, 1989), and monitoring emotions (e.g., Oxford, 1990). Furthermore, to lower the subjects' anxiety, speaking strategies adapted from Weaver \& Cohen, 1997 were used. For Example, positive self-task and positive attitudes were encouraged among the learners and they were asked to give themselves rewards when they had mastered learning goals successfully. The participants were informed of different kinds of strategies that could be available to them. The teacher tried to help them to understand how to organize and use them systematically and effectively. They were also instructed to transfer the strategies they have mastered to new language learning and use contexts.

Moskowitz' activities were practiced with the participants to lessen their anxiety level in EFL classroom. The students enjoyed relaxation exercises like sitting comfortably, and straight, and inhaling and exhaling deeply and slowly. At the end of each week, the participants were given a guided journal that was adapted from Nunan, (1996) and were asked to complete it. These journals contained the following sentence starters which students were asked to complete:

- This week I studied:

- This week I learned:

- This week I used my English in these places:

- This week I spoke English with these people:

- This week I made these mistakes:

- My difficulties are:

- I would like to know:

- I would like help with:

- My learning and practicing plans for next week are:

During six weeks, the control group worked on conventional ways of foreign language learning such as reading texts and answering the given questions without considering any affective aspects of EFL learning. The experimental group practiced affective strategies based on Oxford's model (1990). In other words, only the experimental group received explicit instruction on affective strategies. Oxford believes that in language learning, affective strategies help learners gain control over their emotions, attitudes, and motivations (Oxford, 1990).

After introducing the treatment, the participants in both experimental and control groups participated in the oral proficiency post-test and completed the questionnaire to determine the effectiveness of explicit affective strategy training on their oral proficiency and anxiety reduction. Data collected from the control and experimental groups were compared in pre and post-tests within and between groups to examine their possible progression before and after the treatment.

\subsection{Oral Pretest and Posttest}

Pre and posttests were two equivalent oral tests that were adopted from Heaton (1975). To score the participants' oral pretest and posttest performance, the Oral Communication Assessment Scale for EFL Students, which was first developed by Nakatani (2005), was used (see table 3.3). The scale included seven different levels and focused on learners' fluency, ability to interact with the interlocutor in a conversation, and flexibility in improving dialogue. Two independent assessors who were EFL teachers were participated in the scoring process. Furthermore, the inter-rater reliability was estimated by running Pearson correlation test to the scores given by the two raters. The inter-rater reliability index came to $(\mathrm{r}=.82)$, which represented a high degree of correlation between the two raters.

Table 3.3 Oral Communication Assessment Scale for EFL Students adopted from Nakatani (2005)

\begin{tabular}{l|l}
\hline Level 7 & $\begin{array}{l}\text { Almost always communicates effectively in the task } \\
\text { Speech is generally natural and continuous. } \\
\text { Can interact in a real-life way with the interlocutor } \\
\text { Can generally develop the dialogue spontaneously with few errors }\end{array}$ \\
\hline Level 6 & $\begin{array}{l}\text { Generally communicates effectively in the task } \\
\text { Is not quite fluent but interacts effectively. } \\
\text { Can generally react flexibly } \\
\text { Makes a positive contribution to the dialogue }\end{array}$ \\
\hline Level 5 & $\begin{array}{l}\text { Communicates reasonably effectively in the task } \\
\text { Is sometimes fluent but with hesitancies. } \\
\text { Can interact comfortably and gain flexibility. } \\
\text { Contributes to the dialogue }\end{array}$ \\
\hline
\end{tabular}




\begin{tabular}{l|l}
\hline Level 4 & $\begin{array}{l}\text { Communicates moderately effectively in the task } \\
\text { Makes some pauses but fairly intelligible } \\
\text { Shows some flexibility } \\
\text { Is somewhat independent of the interlocutor in the dialogue }\end{array}$ \\
\hline Level 3 & $\begin{array}{l}\text { Communicates modestly in the task } \\
\text { Makes frequent pauses but somewhat intelligible. } \\
\text { Shows little flexibility } \\
\text { Can maintain dialogue but in a rather passive way. }\end{array}$ \\
\hline Level 2 & $\begin{array}{l}\text { Communicates marginally in the task } \\
\text { Makes numerous pauses, at times long ones } \\
\text { Still depends on the interlocutor but begins to interact a little with him/her. } \\
\text { Given help, communicates quite. Requires some tolerance from the interlocutor }\end{array}$ \\
\hline Level 1 & $\begin{array}{l}\text { Communicates extremely restrictedly in the task } \\
\text { Can answer simple questions but with numerous long pauses. } \\
\text { Depends on interlocutor with only partial contribution to dialogue } \\
\text { Some questions have to be repeated or rephrased. }\end{array}$ \\
\hline
\end{tabular}

\subsection{Administering the questionnaire}

The English teacher administered the questionnaire to all subjects in both experimental and control groups during the English class. The students were informed that their responses to the questionnaires would be kept strictly private and would have no effect on their course grades. The participants were asked to reflect the type and frequency of the anxiety they normally experience through answering the thirty items of the Foreign Language Classroom Anxiety Scale. The items of the FLCAS were 5-point Likert scale with 1 being 'never or almost never true of me' and 5 being 'always or almost always true of me'. These items asked learners about their perceived level of anxiety both in and out of class. To ensure that the participants completely understood the content of the questionnaire, it was translated into Persian.

The reliability of the 30 items of FLCAS was estimated on a pilot study with 20 students comparable to the participants of the study and Cronbach alpha value was $(\alpha=.87)$. The reliability of the test was acceptable based on Bobko (2001), and Litwin's (1995) criterion of $(\alpha=.70)$ as a minimally acceptable alpha value. Therefore, FLCAS was a reliable instrument to estimate the learners' level of anxiety. One expert in TEFL was invited to check the content validity of FLCAS.

\subsection{Data Analysis Procedures}

Qualitative and quantitative data were gathered through FLCAS and oral tests. Data processing and analyses were done with careful consideration of the objectives of the study as well as of the tools that were developed to meet its objectives. Descriptive statistics including mean rank, standard deviation, and frequency counts were used for each item of the questionnaire. To provide answer to the research questions, the first and second administration of the questionnaire and pre/ post oral proficiency scores for the two groups were analyzed. Quantitative analyses were conducted using the Statistical Package for the Social Sciences (SPSS 16). For the two research questions, dependent and independent samples t-tests were run. For the Likert-scale questionnaire items on the Foreign Language Classroom Anxiety Scale, the qualitative results were summarized, categorized, and analyzed for frequency, mean rank, and standard deviation. Two paired t-tests were conducted to analyze subjects' oral proficiency scores in pre and posttests within groups. Two independent samples t- tests were also run to compare control and experimental groups in terms of their post-test performance. To examine the inter-rater correlation, a Pearson correlation test was run to the results of the two raters' scores for the oral proficiency tests. The means of strategy use in both groups before and after the specific treatment and placebo was compared by running $\mathrm{t}$-test.

\section{Results}

\subsection{The First Research Question}

Tables 4.1 and 4.2 below demonstrate the results of independent samples t-test after six weeks of treatment for both control and experimental groups.

Table 4.1Group Statistics for the post-test scores

\begin{tabular}{llcccc}
\hline & group & $\mathrm{N}$ & Mean & Std. Deviation & Std. Error Mean \\
\hline Post oral score & experimental & 30 & 4.53 & 1.63 & .29 \\
& control & 30 & 3.56 & 1.52 & .27 \\
\hline
\end{tabular}




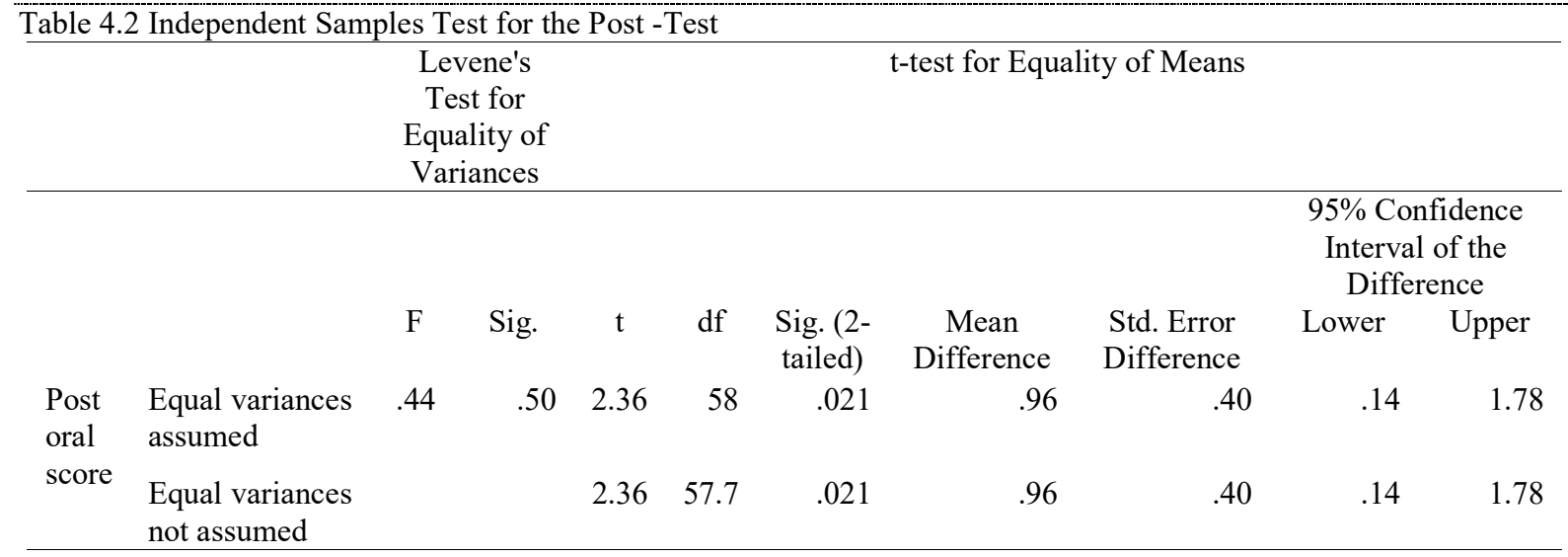

The results of independent samples t-test for the post-test in tables 4.9 , and 4.10 indicate that there was a significant difference between the two groups in their post- test $(\mathrm{p}<0.05)$. According to the data in tables 4.9 , and 4.10, the experimental group considerably outperformed the control group in the post-test. The results indicate that explicit affective strategy training had been effective in improving students' oral language proficiency score in the experimental group and thus the first null hypothesis is rejected. In other words, explicit teaching of affective strategies significantly affects Iranian EFL learners' oral language proficiency. In order to investigate students' progress within groups, two paired t-tests were also run, which showed the subjects' progress in pre-test and post-test that are shown in Tables 4.3 and 4.4.

Table 4.3 Paired Samples Statistics for the Control and Experimental Groups

\begin{tabular}{llcccc}
\hline & Mean & $\mathrm{N}$ & Std. Deviation & Std. Error Mean \\
\hline Pair 1 & Pre- test control & 3.40 & 30 & 1.58 & .29 \\
& Post -test control & 3.56 & 30 & 1.52 & .27 \\
Pair 2 & Pre -test experimental & 2.87 & 30 & 1.13 & .20 \\
& Post -test experimental & 4.53 & 30 & 1.63 & .29 \\
\hline
\end{tabular}

Table 4.4 Paired Samples Test for the Control and Experimental Groups

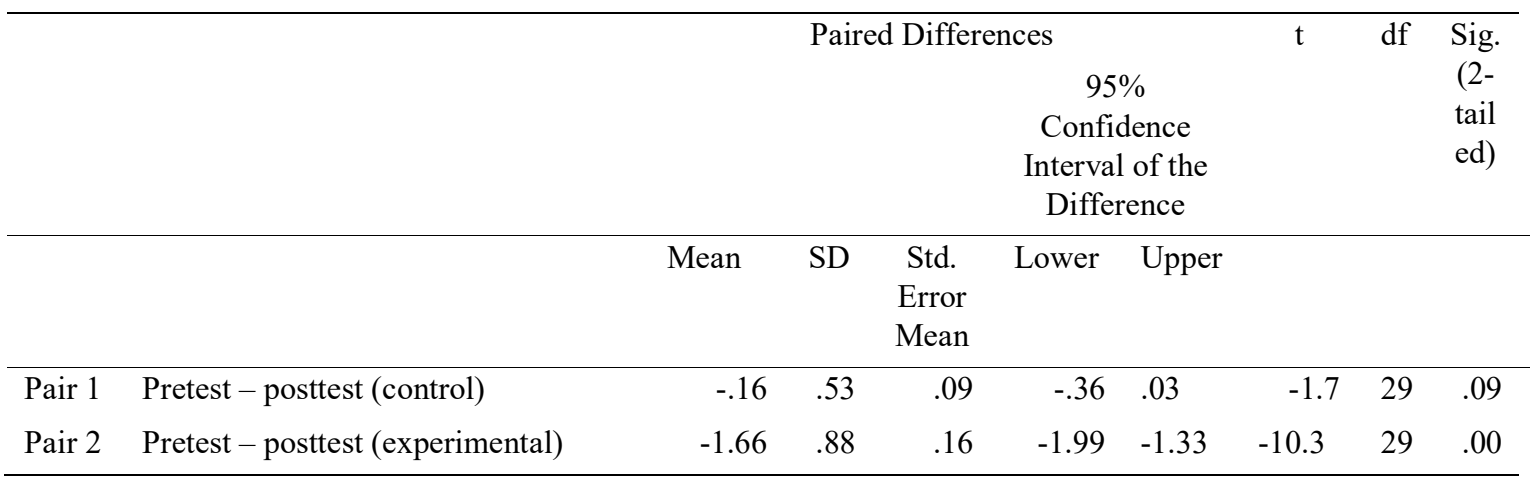

The results of independent samples t-test for the post-test scores in tables 4.9 , and 4.10 indicated that there was a significant difference between the two groups in their post- test $(\mathrm{p}<0.05)$. According to the data in tables 4.9, and 4.10, the experimental group considerably outperformed the control group in the post-test. The results indicated that explicit affective strategy training had been effective in improving students' oral language proficiency score in the experimental group and thus, the first null hypothesis is rejected. In other words, explicit teaching of affective strategies affects Iranian EFL learners' oral language proficiency. 


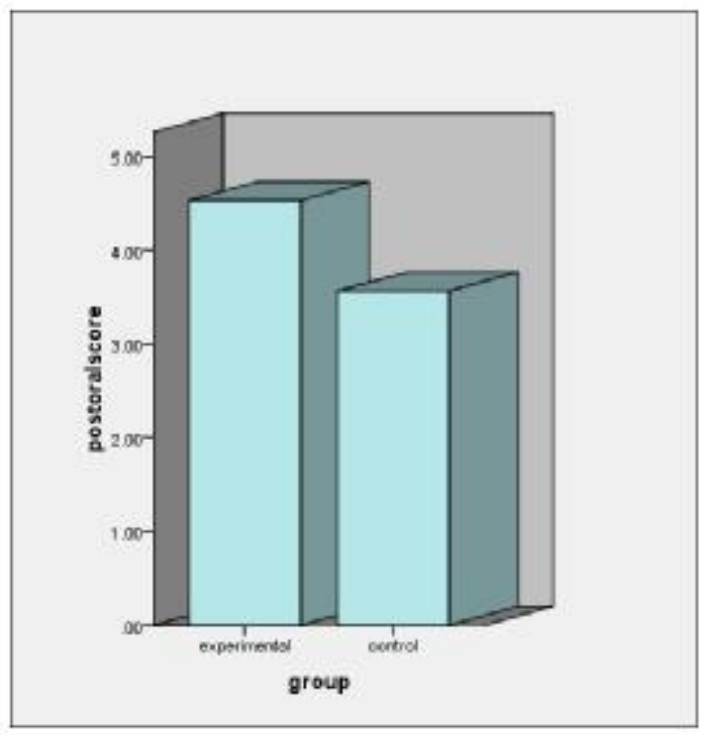

Suss strow Mean

Figure 4.1 The comparison between the two groups on oral post- test at the end of the study

\subsection{The Second Research Question}

Regarding the next question, i.e., whether explicit teaching of affective strategies affects the anxiety control level of the two groups differently, independent samples t-tests results (both at the beginning and at the end of the study) indicated there was a significant difference in the two groups' level of anxiety control simply at the end of the study. The descriptive statistics of these strategies, which are used to control anxiety level in EFL learning.

Table 4.5 Paired Samples Statistics for the Experimental Group

\begin{tabular}{cccccc}
\hline & & Mean & $\mathrm{N}$ & $\begin{array}{c}\text { Std. } \\
\text { Deviation }\end{array}$ & \multicolumn{2}{c}{$\begin{array}{c}\text { Std. Error } \\
\text { Mean }\end{array}$} \\
\hline Pair & Experimental group questionnaire results (first administration) & 2.52 & 30 & .97 & .17 \\
(1 & Experimental group questionnaire results ( second & 3.73 & 30 & .72 & .13 \\
\hline
\end{tabular}

Table 4.6 Paired Samples Test for the Experimental Group

\begin{tabular}{|c|c|c|c|c|c|c|c|c|c|}
\hline & & \multirow{5}{*}{ Mean } & \multicolumn{4}{|c|}{ Paired Differences } & \multirow[t]{5}{*}{$\mathrm{t}$} & \multirow[t]{5}{*}{$\mathrm{df}$} & \multirow{5}{*}{$\begin{array}{l}\text { Sig. (2- } \\
\text { tailed) }\end{array}$} \\
\hline & & & \multirow{4}{*}{$\begin{array}{c}\text { Std. } \\
\text { Deviation }\end{array}$} & \multirow{4}{*}{$\begin{array}{l}\text { Std. } \\
\text { Error } \\
\text { Mean }\end{array}$} & \multirow{3}{*}{\multicolumn{2}{|c|}{$\begin{array}{l}95 \% \text { Confidence } \\
\text { Interval of the } \\
\text { Difference }\end{array}$}} & & & \\
\hline & & & & & & & & & \\
\hline & & & & & & & & & \\
\hline & & & & & Lower & Upper & & & \\
\hline $\begin{array}{l}\text { Pair } \\
1\end{array}$ & $\begin{array}{l}\text { Experimental group questionnaire } \\
\text { results (first administration) } \\
\text { Experimental group questionnaire } \\
\text { results (second administration) }\end{array}$ & -1.20 & .56 & .10 & -1.41 & -.99 & -11.6 & 29 & 0.00 \\
\hline
\end{tabular}

Based on the results of paired samples t- test, there is a significant difference between the mean scores of the experimental group in pre and post administration of the questionnaire $(p<0.05)$, that is: the experimental group's level of anxiety control has been changed significantly after explicit teaching of affective strategies. The following table compares control group's students level of anxiety control at the beginning and at the end of the study.

Table 4.7 Paired Samples Statistics for the Control Group

\begin{tabular}{|c|c|c|c|c|c|}
\hline & & Mean & $\mathrm{N}$ & $\begin{array}{c}\text { Std. } \\
\text { Deviation }\end{array}$ & $\begin{array}{c}\text { Std. } \\
\text { Error } \\
\text { Mean }\end{array}$ \\
\hline \multirow[t]{2}{*}{$\begin{array}{l}\text { Pair } \\
1\end{array}$} & $\begin{array}{l}\text { control group questionnaire results (first } \\
\text { administration) }\end{array}$ & 2.52 & 30 & .98 & .18 \\
\hline & $\begin{array}{l}\text { control group questionnaire results (second } \\
\text { administration) }\end{array}$ & 2.55 & 30 & .97 & .17 \\
\hline
\end{tabular}




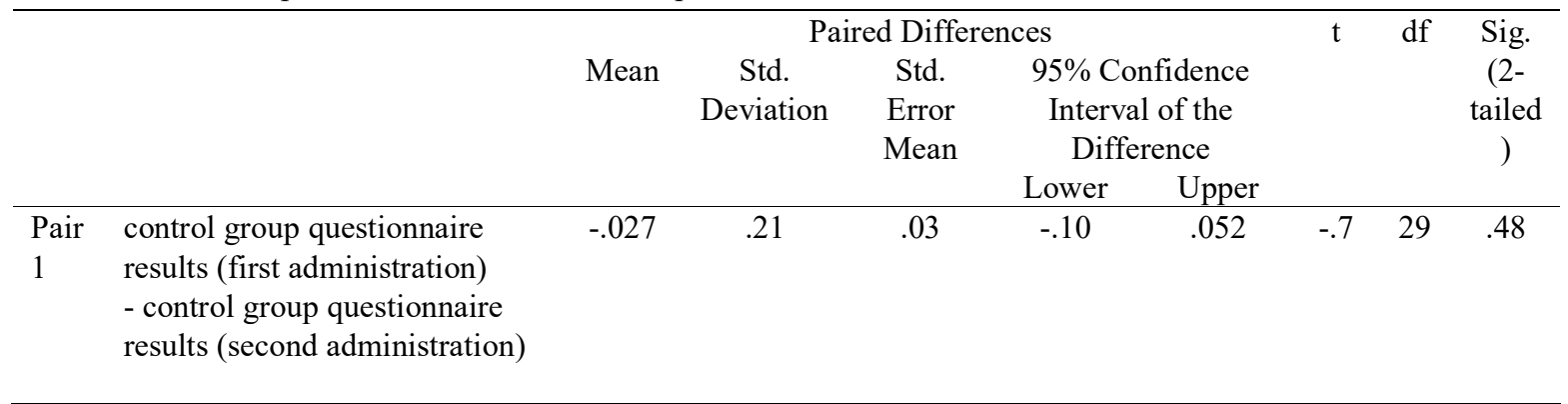

Based on the results of table 4.8, there is no significant difference between the mean scores of the control group in first and second administration of the questionnaire $(\mathrm{p}>0.05)$, that is: the control group participants were almost at the same level of anxiety control both at the beginning and at the end of the study.

In sum while there was not a significant difference between the two groups in terms of level of anxiety control at the beginning of the study, their reported information on the questionnaire regarding their level of anxiety control in EFL learning situations differs significantly at the end of the study. The level of anxiety control for the experimental group is statistically different and higher than that of the control group. Thus, the second null hypothesis was rejected implying that the explicit affective strategy training affects Iranian EFL learners' level of anxiety control.

Table 4.9 Group Statistics for the Two Groups on First and Second Administration

\begin{tabular}{llllll}
\hline & group & $\mathrm{N}$ & Mean & $\begin{array}{c}\text { Std. } \\
\text { Deviation }\end{array}$ & $\begin{array}{c}\text { Std. } \\
\text { Error } \\
\text { Mean }\end{array}$ \\
\hline \multirow{2}{*}{ Questionnaire first administration } & experimental & 30 & 2.52 & .97 & .17 \\
& control & 30 & 2.52 & .98 & .18 \\
Questionnaire second_administration & experimental & 30 & 3.73 & .72 & .13 \\
& control & 30 & 2.55 & .97 & .17 \\
\hline
\end{tabular}

Table 4.10 Independent Samples Test for the two Groups on First and Second Administration

\begin{tabular}{|c|c|c|c|c|c|c|c|c|c|c|}
\hline & & \multicolumn{2}{|c|}{$\begin{array}{l}\text { Levene's } \\
\text { Test for } \\
\text { Equality of } \\
\text { Variances }\end{array}$} & \multicolumn{7}{|c|}{ t-test for Equality of Means } \\
\hline & & \multirow[t]{2}{*}{$\mathrm{F}$} & \multirow[t]{2}{*}{ Sig. } & \multirow[t]{2}{*}{$\mathrm{t}$} & \multirow[t]{2}{*}{ df } & \multirow[t]{2}{*}{$\begin{array}{l}\text { Sig. } \\
(2- \\
\text { tailed })\end{array}$} & \multirow[t]{2}{*}{$\begin{array}{c}\text { Mean } \\
\text { Difference }\end{array}$} & \multirow[t]{2}{*}{$\begin{array}{l}\text { Std. Error } \\
\text { Difference }\end{array}$} & \multicolumn{2}{|c|}{$\begin{array}{l}95 \% \text { Confidence } \\
\text { Interval of the } \\
\text { Difference }\end{array}$} \\
\hline & & & & & & & & & Lower & Upper \\
\hline \multirow[t]{2}{*}{$\begin{array}{l}\text { Questionnaire } \\
\text { first } \\
\text { administration }\end{array}$} & $\begin{array}{l}\text { Equal } \\
\text { variances } \\
\text { assumed }\end{array}$ & .1 & .74 & $\begin{array}{c}- \\
.003\end{array}$ & 58 & .99 & -.00067 & .25 & -.50 & .50 \\
\hline & $\begin{array}{l}\text { Equal } \\
\text { variances } \\
\text { not } \\
\text { assumed }\end{array}$ & & & $\begin{array}{c}- \\
.003\end{array}$ & 57.98 & .99 & -.00067 & .25 & -.50 & .50 \\
\hline \multirow[t]{2}{*}{$\begin{array}{l}\text { Questionnaire } \\
\text { second } \\
\text { administration }\end{array}$} & $\begin{array}{l}\text { Equal } \\
\text { variances } \\
\text { assumed }\end{array}$ & 3.3 & .07 & 5.30 & 58 & .00 & 1.17 & .22 & .73 & 1.61 \\
\hline & $\begin{array}{l}\text { Equal } \\
\text { variances } \\
\text { not } \\
\text { assumed }\end{array}$ & & & 5.30 & 53.52 & .00 & 1.17 & .22 & .73 & 1.61 \\
\hline
\end{tabular}




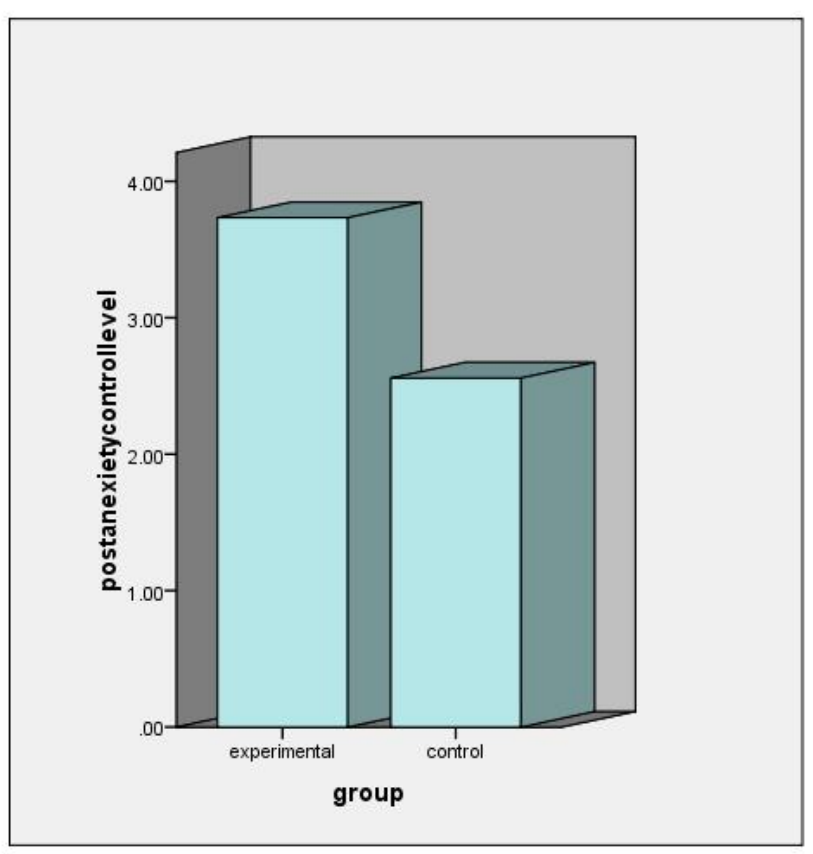

Bars show Mean

Figure 4.2 The comparison between the two groups in terms of their level of anxiety control at the end of the study

\section{Discussion, conclusion and implications of the study}

The results of the study indicated that there was a significant difference between the control and experimental groups in terms of their oral language proficiency. In other words, subjects in the experimental group who received explicit instruction on affective strategies were capable to make use of them to control their level of anxiety and thus improved their foreign language oral proficiency. The findings are consistent with several previous studies on strategy instruction (O’Malley et al.1985b, Thompson \& Rubin 1996, Vandergrift 1999, Habte-Gabr et al, 2006, and Bailey, 1983).

The study included lowering anxiety through deep breathing and relaxation techniques. The main goal was to reduce tension and worries of language learners during EFL learning and to create a friendly, supportive, and relaxed atmosphere that encouraged risk taking. The analysis of the questionnaire indicated that the EFL learners who had received explicit strategy training on affective strategies had lower level of anxiety in English classes. In other words, learners in the experimental group had higher level of anxiety control and self-confidence when they received specific instructions on speaking strategies This is harmonized with what Young (1990) suggested about the role of relaxation techniques in alleviating foreign language anxiety and facilitating learning.

The findings also revealed that deep breathing, and positive statements encouraged the learners in the experimental group to feel relaxed and elevated their self- confidence. This finding supported the results of similar studies (Carrier 2003; Chamot 1990; Duffy, 2002). They believed that learner's knowledge of strategy use enhances their selfconfidence to encounter situations they need to comprehend a task in real life.

This study made use of different opportunities to provide explicit affective strategy use instruction. According to Marefat and Ahmadi Shirazi (2003), instruction and use of learning strategies must be formed as a part of a curriculum through exposing learners with plenty of opportunities to use strategies based on an explicit instruction in order to increase transfer after a time interval. Therefore, one of the reasons for the weak performance of the control group might be due to the fact that they couldn't transfer any strategies since there was no explicit exposure or instruction to strategies. Oxbrow (2005) also believes that strategy training can lead to language proficiency if and only if both students and teachers are aware of the strategies and attentively apply them in their teaching and learning.

In addition, the learners' ratings of the questionnaire disclosed that the subjects used more affective strategies in EFL learning after they received explicit strategy training. This finding is consistent with Nakata's (1999) study that revealed that the effect of affective strategy training was more obvious on perception than on comprehension, especially for EFL learners with low proficiency level. Affective strategies helped to create a non-threatening environment where students were not afraid to make mistakes. This finding supports Krashen's (1983) study, which found a second language is acquired best when affective filter is lowered. Krashen believes that when learners find themselves in a low stress environment they are not afraid to make mistakes.

It can be concluded that explicit affective strategy instruction helped the participants realize that they needed to be more aware of affective factors, use language strategies better, and organize their efforts more effectively. The EFL teacher can use affective training to know learners individually and give them useful tools for language leaning. The relaxed and encouraging atmosphere in the experimental group provided an affective environment for learning and improving their oral language proficiency. The results showed that the experimental group who had positive attitudes and 
willingness towards using affective strategies due to explicit teaching of affective strategies by the teacher, felt less uneasy, nervous and bothered, and more confident and relaxed. The findings of the present study confirmed that foreign language learning is a complicated process. Affective factors are important elements that both teachers and students need to take into consideration to gain a deeper understanding of the nature of language learning and, ultimately, to acquire understanding of themselves. The implementation of affective factors in teaching will encourage trust and working together between teachers and students, intensifies students' responsibility and self-esteem, and stimulate students' learning motivation and interest. In conclusion, affective strategies were significant factors that decreased the level of anxiety among the students.

In terms of the pedagogical implications of the present study, the findings emphasized the importance of affective strategy teaching in EFL contexts and stimulated materials developers to consider strategy use in materials development. Stakeholders should carefully investigate the language-learning context and decide how affective -based classrooms can best satisfy the needs and the interests of the teachers and learners. Teachers also have important role concerning affective strategy use and reducing EFL learners' anxiety. In order to create an effective learning environment, the teachers should create a relaxed environment, and encourage learners to achieve their linguistic goals.

It is suggested that affective factors should be assessed deeply and carefully to determine their actual effect on the learning process and appropriate affective related materials need to be considered in foreign language curricula. It can be implied that instead of forcing EFL learners to practice conversation and oral skill, affective strategies should be introduced to them to reduce their anxiety level and finally improving their oral proficiency. This study has the implication that EFL students' success might be related to their consciousness of the ways of utilizing and practicing affective strategies and suggests that teachers should devote valuable time to the development of affective strategies.

The main limitations of the study resulted from the duration of the study, and the number of the participants used. Moreover, this study did not last long enough to prove how students took advantage from the learning strategies. More longitudinal studies are needed to get information about the efficiency of affective strategies and that how learners can internalize them.

\section{Acknowledgements}

I take this opportunity to express the profound gratitude from depth of my heart to my beloved parents and my little daughter for their kind support, prayers, encouragement, and endless love they have shown to me. You are my greatest strength and you give me the power to go on.

\section{References}

Absy, C.A. (1992). Variations in approaches to ESL: A performance-based analysis of the learning strategies used by Brazilian students. Unpublished doctoral dissertation, Georgetown University.

Arnold, J. (1999). Visualization: language learning with the mind's eye. In J. Arnold (Ed.). Affect in language learning. Cambridge: Cambridge University Press.

Bachman, L. F., \& Palmer, A. S. (1996). Language testing in practice: Designing and developing useful language tests. Oxford: Oxford University Press.

Bailey, K. (1983). Competitiveness and anxiety in adult second language learning: Looking at and through the diary studies. In H. Seliger and M. Long (Eds.). Classroom-oriented research in second language acquisition. Rowley MA: Newbury House.

Barnhardt, S. (1992). Language learning strategies in a high school Russian classroom. Unpublished master's thesis, Georgetown University.

Benson, P. \& Voller, P. (1997). Autonomy and Independence in Language Learning. London: Longman.

Bialystok, E. (1978). A theoretical model of second language learning Language Learning, 28, 69-83.

Bialystok, E. (1983). Some factors in the selection and implementation of communication strategies. In C. Faerch \& G. Kasper (Eds.), Strategies in interlanguage communication (pp. 100-118). Harlow, England: Longman.

Bobko, P. (2001). Correlation and regression (2nd Ed.). Thousand Oaks, California: Sage Publications.

Brown, H. D. (1989). A practical guide to language learning: A fifteen-week program of Strategies for success. New York: McGraw-Hill.

Brown, H. D. (1991). Breaking the language barrier: Creating your own pathway to success. Yarmouth, ME: Intercultural Press, Inc.

Brown, D. H. (2007). Principles of language learning \& teaching. (5th Eds.). Pearson: Longman.

Carrell, P.L. (1998). Can reading strategies be successfully taught? The Language Teacher, 22, 7-14.

Carrell, P.L., Pharis, B.G., \& Liberto, J.C. (1989). Metacognitive strategy training for ESL reading. TESOL Quarterly, 23, 647-678. 
Carrier, P.L. (2003). Improving high school English language learners' second language listening through strategy instruction. Bilingual Research Journal 27(3), 383-410. Retrieved from Proquest database.

Chamot, A. (1987). The learning strategies of ESL students. In A. Wenden \& J. Rubin (Eds.), Learner strategies in language learning (pp. 71-83). New York: Prentice Hall.

Chamot, A. U. (1993). Student responses to learning strategy instruction in the foreign language classroom. Foreign Language Annals, 26 (3), 8-31.

Chamot, A. (1999a). How children in language immersion programs use learning strategies. In M.A. Kassen (Ed.), Language learners of tomorrow: Process and promise (pp. 29-59). Lincolnwood, IL: National Textbook Company.

Chamot, A.U., \& Küpper, L. (1989). Learning strategies in foreign language instruction. Foreign Language Annals, 22, 13-24.

Chamot, A.U., \& O’Malley, J. M. (1994a). The CALLA handbook: Implementing the Cognitive Academic Language Learning Approach. Reading, MA: Addison- Wesley.

Chou, Y. (2004). Promoting Learners' Speaking Ability by Socio-affective Strategies. The Internet TESL Journal, 10(9). Retrieved from http://iteslj.org/Articles/Chou- Socioaffective.html

Cohen, A.D. (1990a). Language learning: Insights for learner, Teachers, and researchers. NY: Newbury House/Harper \& Row.

Cottrell, S. (1999). The study skills handbook. London: Macmillan Press.

Curran, C. (1972). Counselling-Learning: A Whole-Person Model for Education. New York: Harcourt Brace Jovanovich.

Dorney, Z. (1995). On the teachability of communication strategies. TESOL Quarterly, 29, 55-58.

Dörnyei, Z. (2001). Teaching and researching motivation. Harlow: Longman.

Duffy, G. (2002). The case for direct explanation of strategies. In C. Block \& M. Pressley (Eds.). Comprehension instruction: Research-based best practices (pp. 28_41). New York: Guilford Press.

Finch, A. .E., (2000). A formative evaluation of a task-based EFL program for Korean university students. Unpublished Ph.D. Thesis. Manchester University, U.K. Retrieved from http://www.finchpark.com/afe/index.htm

Goh, C., \& Kwah, P. (1997). Chinese ESL students' learning strategies: A look at frequency, proficiency, and gender. Hong Kong Journal of Applied Linguistics, 2 (1), 39-53.

Green, J.M., \& Oxford, R.L. (1995). A closer look at learning strategies, L2 proficiency, and gender. TESOL Quarterly, 29, 261-297.

Hall, J. (2001). Methods for teaching foreign languages: creating a community of learners in the classroom. Upper Saddle River, NJ: Prentice-Hall, Inc.

Habte-gabr, E. (2006). The importance of socio-affective strategies in using EFL for teaching mainstream subjects. Humanising English teaching, 8(5). Retrieved from http://www. hltmag.co.uk/sep06/sart02.htm

Heaton, J. B. (1975). Language Testing. Modern English Publications.

Hedge, P. (1993). Key Concepts in ELT: Learner Training. ELT Journal, 47 (1), 92-93.

Horwitz, E. K., Horwitz, M. B., \& Cope, J. (1986). Foreign language classroom anxiety. The Modern

Language Journal, 70, 125-132.

Horwitz, E. K. (2001). Language Anxiety and Achievement. Annual Review of Applied Linguistics, 21, 112-127. Retrieved from http://dx.doi.org/10.1017/S0267190501000071

Krashen, S. D. (1982). Principles and practice in second language acquisition. Oxford: UK: Pergamon Press.

Litwin, M. (1995). How to Measure Survey Reliability and Validity. Survey Kit, 7. A. Fink. Beverly Hills, CA, Sage Publications.

Lott-Lage, M.H. (1993). Metacognition in native and foreign language reading: A multiple-case study of Brazilian adult readers. Unpublished doctoral dissertation, Georgetown University, Washington DC.

Lozanov, G. (1979). Suggestology and outlines of suggestopedy. New York: Gordon and Breach.

MacIntyre, P. \& Gardner, R. (1991). Language anxiety: Its relation to other anxieties and to processing in native and second languages. Language Learning, 41, 513-534.

McDonough, S. (1995). Strategy and skill in learning a foreign language. London: Edward Arnold.

Marefat, H. \& Ahmadi Shirazi, M. (2003). The impact of teaching of direct learning strategies on the retention of vocabulary by EFL learners. The Reading Matrix, 3 (2), 47-62. Available: http://www.readingmatrix.com/articles/marefat_shirazi/article.pdf

McDonough, S.H. (1995). Strategy and skill in learning a foreign language. London: Edward Arnold.

Mendelsohn, D. (1994). Learning to listen: A strategy-based approach for the second language learner. San Diego, CA: Dominie Press. 
Moskowitz, G. (1978). Caring and Sharing in the Foreign Language Class: A Sourcebook on Humanistic Techniques. Rowley, MS.: Newbury House.

Nakatani, Y. (2005). The effects of awareness-raising training on oral communication strategy use. Modern Language Journal, 89, 76-91.

Nunan, D. (1996b). Learner strategy training in the classroom: An action research study. TESOL Journal, 6, 35-41.

O’Malley, J.M., \& Chamot, A.U. (1990). Learning strategies in second language acquisition. New York: Cambridge University Press.

O'Malley, J. M., Chamot, A., Stewner-Manzares, G., Kupper, L. \& Russo, R. (1985). Learning strategy applications with students of English as a second language. TESOL Quarterly, 19 (3), 557-584

O’Malley, J.M., Chamot, A.U., Stewner-Manzanares, G., Küpper, L., \& Russo, R.P. (1985). Learning strategies used by beginning and intermediate ESL students. Language Learning, 35, 21-46.

Omori, M. (1992). Learning strategies in the Japanese classroom. Unpublished master's thesis, Georgetown University.

Othman, J. \& Vanathas, C. (2006). Topic Familiarity and its Influence on Listening Comprehension. The English Teacher Journal, 36, 19-32.

Oxbrow, G. (2005). Writing, reflection and learning: an interactive approach. Journal of Porta Linguarum, 4, $167-184$.

Oxford, R.L. (1990b). Language learning strategies: What every teacher should know. New York: Newberry House Publishers. Now Boston: Heinle \& Hienle.

Oxford, R.L. (1996b). Language learning strategies around the world: Cross-cultural perspectives. Honolulu: Second Language Teaching \& Curriculum Center, University of Hawaii.

Oxford, R.L., \& Burry-Stock, J.A. (1995). Assessing the use of language learning strategies worldwide with the ESL/EFL version of the Strategy Inventory for Language Learning (SILL). System, 23(2), 153-175.

Oxford, R. L., \& Nyikos, M. (1989). Variables affecting choice of language learning strategies by university students. Modern Language Journal, 73 (3), 291-300.

Peacock, M., \& Ho, B. (2003). Student language learning strategies across eight disciplines. International Journal of Applied Linguistics, 13 (2), 179-200.

Politzer, R. L. (1983). An exploratory study of self-reported language learning behaviors and their relation to achievement. Studies in Second Language Acquisition, 6 (1), 54-65.

Schumann, J. H. (1997). The neurobiology of affect in language. Malden, MA: Blackwell Publishers.

Schumann, J. H. (2001). Learning as foraging. In Z. Dornyei \& R Schmidt (Eds.). Motivation and second language acquisition (pp. 21-28). Honolulu: University of Hawai'i, Second Language Teaching \& Curriculum Center.

Scimonelli, P. (2002). Language learning strategies: Helping the students find "il metodo". In Norwich institute for language education: Main assignment. Retrieved from http://web.tiscalinet.it/colabianchi/NorwichSITE/BRUNA\%20main\%20assign.-\%20LLS.doc

Stevick, E. W. (1980). Teaching languages: A way and ways. Rowley, MA: Newbury House.

Tamada, Y. (1996) the relationship between Japanese learners' personal factors and their choices of language learning strategies. Modern Language Journal, 80, pp. 120-131.

Thompson, I. \& Rubin, J. (1996). Can strategy instruction improve listening comprehension? Foreign Language Annals, 29(3), 331-342.

Thompson, I., \& Rubin, J. (1996). Can strategy instruction improve listening comprehension? Foreign Language Annals, 29(3), 331-341.

Vandergrift, L. (1992). The comprehension strategies of second language (French) learners. Unpublished doctoral dissertation, University of Alberta, Edmonton, Alberta, Canada.

Weaver, S.J., \& Cohen, A.D. (1997). Strategies-based instruction: A teacher-training manual. Minnesota: Center for Advanced Research on Language Acquisition, University of Minnesota, MN.

Yang, N. D., (1992). Second language learners' beliefs about language learning and their use of learning strategies: A study of college student of English in Taiwan. Dissertation Abstracts International, 53, 2722A.

Young, D. J. (1990). An investigation of students' perspectives on anxiety and speaking. Foreign Language Annals, $23(6), 539-553$.

Young, D. J. (1991). The relationship between anxiety and foreign language oral proficiency ratings. In E.K. Horwitz \& D. J. Young (Eds.). Language anxiety: From theory and research to classroom implications (pp. 57-63). Englewood Cliffs, NJ: Prentice Hall.

Zheng, Y. (2008). Anxiety and second/ foreign language learning revisited. Canadian Journal for New Scholars in Education, 1(1), 1-12. 